KS. WALDEMAR W. ŻUREK SDB - LUBLIN

\title{
SACRUM CONNECTING NATIONS
}

At the end of 2015 in two towns in south eastern Poland: Chełm and Lublin, on the Polish-Ukrainian border, there were the days during which we had the opportunity to learn the history of the image of Our Lady of Chełm ${ }^{1}$, and the spiritual sphere of the Polish-Ukrainian borderland over the centuries.

The UCRAINICUM Centre of the John Paul II Catholic University of Lublin, the General Consulate in Lublin, the Catholic Association "Civitas Christiana" and the Institute of Modern Languages of the State Higher Vocational School in Chełm, in cooperation with the Honorary Consulate of Ukraine in Chelm, the Association "Common Roots" and the European Foundation for Social Activity organized, on 14-15 December 2015 in Chełm and Lublin, an international conference devoted to the 250th anniversary of the coronation of the image of Our Lady of Chelm².

${ }^{1}$ The Icon of the Mother of God of Chełm was to be the dowry of Princess Anne from Constantinople (the sister of the Byzantine emperor Basil II the Bulgar Slayer), the wife of Prince (Knyaz) of Kiev (from 980) Vladimir the Great (956-1015), who accepted Christianity in the Eastern rite (Orthodox) from Constantinople and recognized the Orthodox faith as the state religion. In 988 in the town of Kherson on the Black Sea, Vladimir was baptized and given the name Vasily (Basil). A year later he married Princess Anna. Currently, in the central altar of the Basilica of the Nativity of the Blessed Virgin Mary in Chełm there is a replica of this image - the image of the Madonna and Child from 1938, whose original is in the Museum of Volyn Icons in Lutsk. In 1915, the painting was taken from Chelm to Russia and disappeared there. In 1919, a copy of this image, which was found in the attic, was placed in the altar, twenty years later it was replaced with a new copy made by Władysław Ukleja and this image is the one that has been worshipped. J. Stefański, $Z$ dziejów kultu obrazu Matki Boskiej Chetmskiej, [in:] „Nasza Przeszłość” volume 66 (1986), pp. 159-190.

${ }^{2}$ The image of Our Lady of Chelm was crowned three times: on 15 September 1756 by Archbishop of Smolensk Herakliusz Lizański; 7 July 1946 (a copy) by Bishop of Lublin Stefan Wyszyński; on 8 September 1957 (a copy) by bishop of Lublin Piotr Kałwa. J. Zięba, Dzieje jednego obrazu. Opowieść o Cudownej Ikonie Matki Boskiej Chetmskiej, Lublin 2005. 
The miraculous painting (a copy) of Our Lady of Chełm is now located in the Roman Catholic parish church in Chełm on the Hill - in the Basilica of the Nativity of the Blessed Virgin Mary ${ }^{3}$.

On December 14 at 3pm, in the Marian Basilica in Chełm, a retired ordinary of the diocese of Kharkiv and Zaporizhzhia (Ukraine) Rev. Marian Buczek presided the Mass concelebrated at the beginning of the session. Before the Eucharist started, the custodian of the Basilica Rev. Stanisław Kądziołka greeted people who gathered in the church wishing them extensive and fruitful debates and academic discussions. In his homily, bishop Buczek stressed the importance of contacts between the Poles and Ukrainians in a field of religion, economy and politics.

The opening of the conference was held in the hall of the Senate of the State Higher Vocational School in Chełm. The conference began with a letter written by the President of the Republic of Poland Dr Andrzej Duda to the organizers and participants of the conference, in which the author stressed the importance of meetings and academic debates on the history of neighbouring nations: the Poles and Ukrainians. In the first session there were four speakers. Bishop Marian Buczek of Lviv spoke about: The Polish-Ukrainian borderland as an area of spiritual communion and cooperation. Professor Ryszard Szczygieł from Lublin discussed the following topic: The sacred map of Chetm and the district of Chetm and in the Middle Ages. Olga Osadczy (Lviv-Chełm) presented the following topic: The Church Union of Prince Daniel Romanowicz as an attempt to restore the unity of Christians at the crossroads of tradition of the East and West. Zygmunt Gardziński from Chelm talked about: The cult of the Virgin Mary of Chetm after 1944. At the end of the first session there was a few-minute discussion.

The next day, December 15, morning and afternoon sessions took place in the building of the Catholic University of Lublin. After opening the first session by Professor Włodzimierz Osadczy, an organizer and host, and after his greeting the guests and listeners, the first lecturer Dr Jan Sęk (Lublin) talked about: The

${ }^{3}$ In the place of the current Basilica there was an Orthodox church of the same name, founded about 1260 by Daniel Romanowicz. Following the Union of Brest in 1596, the church became the cathedral of the Greek Catholic rite. After the reconstruction of the cathedral after a fire in 1640 and after adding the transept in 1711, the church was in danger of collapsing, so bishop Felicjan Włodkowic (1731-1756) ordered its demolition and the construction of a larger one, which was begun in 1735 and completed in 1756. The new church was built in the style of Western European Baroque, in imitation of Roman Catholic churches (choir, confessionals, the central altar and five side-altars), and the interior was devoid of the features typical of the Greek Orthodox churches. In 1802, the church burned down again. It was rebuilt in 1827. After the dissolution of the union in 1875, it was rebuilt and converted to the Orthodox Cathedral of the Byzantine-Ruthenian type. In 1915, it was taken over by the Austrian troops and changed into an arms and ammunition depot- until 2 November 1918. In May 1919, this sacral object was taken over by the Roman Catholic Church - the Jesuits, who converted it into a monastic church. In 1935, the church was taken over by diocesan priests and a new parish in Chełm was erected. In May 1940, the Germans gave the church to the Orthodox Ukrainians. In November 1940, the Orthodox Cathedral of the Nativity of Our Lady became the seat of the bishop of the Diocese of Chelm and Podlasie. In August 1944, the cathedral was given to the Catholics again and it became the Roman parish church. In 1988, Pope John Paul II granted the church the title of Minor Basilica. K. Janczykowski, Góra Chetmska, jej Królowa i lud, Chełm 1946. 
military and sacral complex in Stotpień near Chetm. Professor Andrzej Gil from Lublin presented the following topic: The organization of Eastern Churches of the district of Chetm. Rev. Professor Waldemar Witold Żurek of the Catholic University of Lublin discussed the following topic: The image of Our Lady of Chetm: history, tradition, cult. Orest Małyta from Lviv spoke about: The images of Our Lady of "Hodegetria" based on the collection of the Lviv Museum of the History of Religion. The last speaker of the morning session - Professor Włodzimierz Osadczy from Lublin presented a paper titled: The coronation of the image of Our Lady of Chetm in the context of the Polish Baroque religious tradition.

The afternoon session was continued in the lecture hall of the Collegium of the John Paul II Catholic University of Lublin. Continuing the debates, Professor Andrzej Melkow from Moscow recalled the theme: Russian Orthodox Church as a tool of the policy of Russification of the Chetm district. Another speaker, Professor Jan Lewandowski from Lublin talked about The Tsarist repression of the Chetm Uniates in the context of the policy of imperial Russia. Professor Waldemar Bednaruk (Chełm-Lublin) presented the following topic: The tolerance ukase of 1905 and its impact on the religious situation in the Chetm district. The last speaker of this session - Oleg Bednaruk from Lutsk talked about: 1938. A Martyrology of the Orthodox churches in Chetm.

The afternoon session included five papers. The first speaker was Professor John Partacz from Koszalin: The policy of "Ukrainization" of the religious life of the Orthodox population in Chetm at the time of Metropolitan bishop Ilarion Ohijenko. Dr Miroslawa Kawecka from Chelm presented the following topic: Our Lady of Chetm in the works of the poets of Chetm. Dr Tomasz Zygmunt from Chelm prepared a lecture: Sacral function of Latin in the area of Western civilization. Marcin Sułek from Lublin talked about: The Mother of God of the Uniates from Chetm. Recoronation of the image of the Blessed Virgin Mary of Chetm on 7 July 1946. The last speaker Konstanty Czawaga from Lviv presented a paper titled: The identity of the Ukrainian people coming from the district of Chetm and southern Podlasie. The national and religious aspect. At the end of the conference there was a presentation of the Polish-Ukrainian cooperation, the directions of its further development and intensification, and the expected consequences for neighbouring countries.

\section{$* * *$}

The icon of Our Lady of Chelm has been considered miraculous since the mid-thirteenth century, and its cult dates back to the early eleventh century. The first book describing the history of the cult of the miraculous image and miracles was written by Jakub Susza ${ }^{4}$ (Phoenix ...) published in 1646 in Zamość. In his

\footnotetext{
${ }^{4}$ Bishop Jakub Susza (1610-1687) - a Basilian monk. In 1649 he became an administrator of the Greek Catholic diocese of Chełm. He was removed from office by the Orthodox Metropolitan bishop of Kiev S. Kossów, but later he regained it with the help of King Jan II Kazimierz. In 1652, he became the bishop of Chełm, where he stayed until his death. At that time, he convened 6 diocesan synods. He is the author of the book: Phoenix Tertiato Redivivus Albo Obraz Starozitny Chetmski Panny y Matki Przenajswiętszey Stawą Cudownych swoich dziet potrzecie ożyly. Praca Jaśnie
} 
book, the author provided information about the miracles through the intercession of Our Lady of Chełm. He presented 693 miracles to the moment of publishing the book. Most miracles were connected with human health, including the birth of a child. There was also a significant number of miraculous healings of animals. Another group included the miraculous events on the battlefield, mainly wars with Russia and Turkey. Our Lady of Chełm was attributed to have the power of stopping the plague and healing the sick, the power of fire fighting, finding stolen things, and she affected the acceptance of Catholicism ${ }^{5}$.

Chełm was the place of pilgrimages of the local faithful, as well as people from more remote places, who came there individually and in organized groups. People with whom miraculous events are associated came from 208 villages. In most cases they lived in the district of Chełm. There were also pilgrims from larger Polish cities such as Sambor, Warsaw, Krakow, Vilnius, Pinsk.

In the history of the image of Our Lady of Chelm and its cult by the Orthodox faithful, Greek Catholics and the Roman Catholics, the image of the Virgin Mary wandered through the cities, towns, battlefields and stopped in the places where Polish kings were stationed. The image of Our Lady of Chełm had no permanent place in any church. Over centuries it travelled through 32 towns and Polish cities, returning three times to Chełm, where it is still worshiped by the believers.

Przewiel. J.M.X. Jakuba Suszy Episkopa Chetmskiego y Betskiego, Archimandrity Z Dozwoleniem Vrzędu należytego, Roku MDCLXXXIV, Zamość. J. Kania, Chetmska diecezja - III. Diecezja unicka, [in:] EK, volume 3, Lublin 1985,columns 133-136; D. Wereda, Susza Jakub, [in:] EK, volume 18, Lublin 2013, columns 1232-1233.

${ }^{5}$ J. Stefański, Z dziejów kultu obrazu Matki Boskiej Chetmskiej, pp. 177-185. 